Revista Complutense de Historia de América ISSN: $1132-8312$

http://dx.doi.org/10.5209/RCHA.61081

\title{
Viviendo entre cristianos como gentiles y entre españoles como bárbaros". Borracheras indígenas, doctrina cristiana y migración forzosa en Chile central, $1575-1655^{1}$
}

\author{
Hugo Contreras Cruces ${ }^{2}$
}

Recibido: 9 de septiembre de 2016 / Aceptado: 6 de mayo de 2017

Resumen. En el último cuarto del siglo XVI, según la percepción del Cabildo de Santiago y más tarde de otras autoridades y funcionarios, hubo un resurgimiento de las "borracheras" indígenas. Estas, en principio, solo fueron concebidas como espacios de juerga y descontrol etílico y sexual sin mayor significación ritual o política, sin embargo, con la llegada de los migrantes indígenas forzosos traídos desde la Araucanía y Chiloé se comenzaron a representar como espacios sociales donde la adoración a los antiguos espíritus tutelares y la apostasía se combinaban con la conspiración rebelde, reavivando los más hondos temores españoles de que la guerra de Arauco se trasladara clandestinamente al interior del reino de Chile, lo que era alimentado no solo por la incesante repetición de borracheras y juegos de "chueca", sino también por los rumores que comúnmente corrían por las calles de la capital chilena.

Palabras clave: Borracheras; rebelión; migración forzosa; evangelización; Chile; siglos XVI-XVII.

\section{[en] "Viviendo entre cristianos como gentiles y entre españoles como bárbaros". Indigenous Drunkenness, Christian Doctrine and Forced Migration in Central Chile, 1575-1655}

\begin{abstract}
In the last quarter of the 16th century, there was, as perceived by the Town Council of Santiago and later by other authorities and officials, a resurgence of the indigenous drunkenness. In the beginning, these binges were understood as opportunities for revelry and uncontrolled drinking and sexual acts, that were without important political or ritual significance. Nevertheless, with the arrival of forced immigrants from the Araucanía Region and Chiloé, they began to be represented as social spaces where the worship of ancient tutelary spirits and the apostasy were combined with the rebel conspiracy, reviving the deepest fears among the Spanish that the Arauco would spread underground to the interior the Kingdom of Chile, nurtured by the endless repetition of drunkenness and "chueca" games and by the rumors that commonly spread through the streets of the Chilean capital.
\end{abstract}

Keywords: Drunkenness; Rebellion; Forced Migration; Evangelization; Chile; 16-17th Centuries.

Sumario. 1. Introducción. 2. Costumbres indígenas, doctrina cristiana y control social en las postrimerías del siglo XVI. 3. Tiempos rebeldes, migración forzosa y juegos de chueca. 4. Conclusiones. 5. Referencias bibliográficas.

1 Este artículo fue escrito entre Sevilla y Santiago de Chile, y es resultado del proyecto de investigación Fondecyt regular $\mathrm{n}^{\circ} 1150614$ "Desnaturalización" y esclavitud indígena en fronteras americanas: La esclavitud de mapuches de la Araucanía y la de los indios de Nueva España, Río de la Plata y Brasil (siglos XVI-XVII). Agradezco los estímulos y comentarios de Nelson González, Mauricio Rojas, Viviana Gallardo y Jaime Valenzuela.

2 Escuela de Historia, Universidad Academia de Humanismo Cristiano (Chile).

E-mail: hucontrerasc@yahoo.com 
Cómo citar: Contreras Cruces, H. (2018) "Viviendo entre cristianos como gentiles y entre españoles como bárbaros". Borracheras indígenas, doctrina cristiana y migración forzosa en Chile central, 15751655, en Revista Complutense de Historia de América 44, 91-113.

\section{Introducción}

Los [indios] de esta [ciudad] y [los] coxidos en la guerra que son los mas que en sus terminos sirven a los españoles se conspiraron y trataron de rebelarse contra la real corona y de matar a los beçinos y moradores y tenian repartidas entre si todas las mugeres desta dicha ciudad $[\ldots]^{3}$.

Con estas palabras el capitán Jerónimo de Molina encabezó una de las preguntas de su información de méritos y servicios. En ella sindicaba en general a los responsables de los graves hechos que, en su gestión como corregidor de Santiago, había logrado evitar algunos años antes ${ }^{4}$; cuando la flecha de la guerra ${ }^{5}$ habría llegado hasta el Norte chico y Chile central, introduciendo la rebeldía entre los indígenas de la zona a través de quienes en los años previos (de modo voluntario, aunque principalmente de manera forzada y violenta), habían llegado desde la Araucanía,

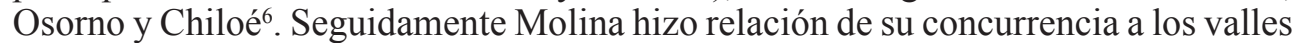
de Aconcagua y Quillota junto a una cuadrilla de hombres armados, donde ahorcó algunos conspirados; y en Santiago, lugar en que aplicó "castigos ejemplares" a los que consideró mayormente implicados. Tal eufemismo hacía referencia a las duras penas que se solían aplicar a los responsables de crímenes tan graves como la rebelión, las que podían incluir la decapitación, la mutilación, el descuartizamiento y la exhibición pública de sus restos ${ }^{7}$.

No se sabe cómo el corregidor recibió esta información. Quizás fue de un traidor, o se trató de un rumor como los muchos que corrían por Santiago, los cuales aumentaban el miedo y la zozobra derivados de las continuas derrotas españolas en la guerra contra el mapuche. Pero cuál fuera la forma en que Molina se enteró de este intento rebelde, con ello se hacía realidad uno de los grandes temores de los españoles, al menos a nivel de su representación. Éste era el que la comunicación clandestina entre los migrantes forzosos venidos de la Araucanía a los valles centrales y sus parientes insurrectos, no se había cortado con su extrañamiento. Al contrario, ella se

3 Probanza de méritos y servicios del capitán Jerónimo de Molina. Santiago de Chile, 18-XI-1610. Archivo General de Indias [España] (en adelante AGI), Chile, 34, sin foliar. Sus palabras fueron confirmadas por los testigos de la probanza. Algunos de ellos, incluso, aportaron información detallada de las acciones del corregidor y del destino de los indios capturados.

4 Esta supuesta conspiración se dio en el marco de la guerra hispano-mapuche librada entre 1598 y 1604 . Sobre esta última, véase: Barros Arana, 2000 [1884]; Errázuriz, 1908; Palma, 1995; Goicovich, 2006: 93-154.

5 Entre los mapuches se debían efectuar un conjunto de acciones reales y rituales para declarar la guerra. Una de ella era el enviar un mensajero con una flecha ensangrentada, o el despojo de un enemigo, lo que debía ser presentado a quienes eran convocados para sumarse al conflicto. Quienes lo aceptaban se constituían en parte de los alzados. Contreras, 2013: 72.

6 Sobre los alzamientos en Chile central o sus intentos, en una perspectiva sintética y descriptiva: Ruiz, 1999.

7 Respecto de los “castigos ejemplares" en la conquista y colonización de América: Espino, 2013: 81-176. 
había concretado en la extensión del alzamiento al interior de Chile sin que nadie se hubiera dado cuenta, sino hasta que éste se encontraba ad portas de realizarse.

Si anteriormente se analizó otra rebelión fallida, y se hizo referencia a una "memoria del miedo al otro", que atenaceaba a los españoles, y que los llevó a culpar casi sin reflexión a los inmigrantes mapuches que vivían en los sectores rurales cercanos a Santiago ${ }^{8}$, en esta oportunidad lo que nos interesa es reconstituir cómo se fue generando esa sensación de continua sospecha contra los habitantes indígenas de Chile central y el Norte chico. Indagar si ella tenía algún asidero en la realidad, pero por sobre todo, preguntarse cuáles eran los procesos sociales y culturales que, amén a la llegada de migrantes forzosos y, más tarde, de esclavos mapuches, estaban viviendo los llamados "indios" de estos parajes y que explicarían los temores de los españoles. Claramente el solo exilio de los cautivos no anulaba necesariamente sus redes parentales, el uso de su idioma y su cosmovisión. A su vez, al ser empleados en estancias y chacras se les brindaba la posibilidad de crear nuevos parentescos, y de transmitir a sus compañeros de trabajo y de residencia, su religión y su lengua.

En tal sentido, planteamos que en Chile central y el Norte chico la llegada de migrantes forzosos produjo una revitalización de la sociedad indígena colonizada, la que se expresó en la reintroducción de ceremonias y actos de indudablemente contenido ritual, como el palín y las borracheras, aunque en un principio los españoles interpretaran estas últimas solo como espacios de juerga y disolución moral. En un contexto en el que la evangelización era frágil; donde originarios y migrantes hablaban un mismo idioma, residían juntos y se emparentaban, la sospecha de que se produjera un alzamiento estaba siempre presente, más aún si los indígenas se hallaban pobremente integrados a la sociedad colonial, que era precisamente lo que en esos momentos sucedía.

\section{Costumbres indígenas, doctrina cristiana y control social en las postrimerías del siglo XVI}

Atento a las muchas borracheras que los indios hacen en esta ciudad y sus términos, y los muchos daños y agravios que entre los indios suceden y muertes entre ellos mismos y ofensas que se hacen a Dios, nuestro señor, como por expiriencia estos señores deste Cabildo, o la mayor parte dellos, han visto [...]".

Luego de mucho tiempo de haberlo tratado, el 24 de julio de 1568 el Cabildo de Santiago dedicó parte de su sesión semanal a la continua ocurrencia de borracheras entre los indígenas de la ciudad y de sus alrededores. A diferencia de otras oportunidades, tal acta fue mucho más detallada. En ella se consigna que éstas se hacían los domingos y los días de fiesta, que se organizaban en sus rancheríos, que en ellas ocurrían muchas muertes, y graves ofensas a Dios. Junto con este diagnóstico, ordenaron que el corregidor, y luego los propios ediles, salieran a recorrer los alrededores de

\footnotetext{
Contreras, 2013.

Acta del Cabildo de Santiago de 24 de julio de 1568. Santiago de Chile, 24-VI-1568. Colección de historiadores de Chile y documentos relativos a la historia nacional [Chile] (en adelante CHCh), t. XVII, 1898: 237.
} 
Santiago para "deshacerlas", prender a sus participantes, y castigarlos sumariamente con azotes y cortes de pelo ${ }^{10}$.

Dichas borracheras se representaban como juergas apolíticas y pobremente influenciadas por las religiones nativas, asociándose a la disolución moral y a los excesos indígenas. Tampoco se concebían como espacios de resistencia o de confabulación. Lo anterior a pesar de que los castellanos en general, y en particular quienes tenían experiencia en la guerra del sur del reino, sabían que en ese contexto lo que ellos llamaban borracheras eran grandes reuniones en las cuales jefes, guerreros y machis se preparaban para la batalla o celebraban la victoria. Ellas incluían actos rituales, bárbaros a los ojos hispanos, pero de indudable sentido simbólico: como eran el hacer predicciones a partir del análisis de las vísceras de un animal sacrificado, o ejecutar a un prisionero y, junto a la música y las reuniones entre los líderes militares que se sucedían durante el festejo, no faltaban la chicha u otras bebidas alcohólicas $^{11}$. Eran, por lo tanto, el antecedente más directo para sospechar de un ataque y, de hecho, ello se reflejaba tanto en las crónicas como en las probanzas de méritos de soldados y capitanes, muchos de los cuales dieron cuenta de haber atacado por sorpresa una "junta" rebelde aprovechando esta coyuntura ${ }^{12}$.

A pesar de su mayor detalle, la descripción referida no era cualitativamente diferente de lo que una década atrás el propio Cabildo había discutido. Tampoco habían variado las penas a las que los "borrachos" eran condenados. Un elemento que se echaba de menos, era el de la asociación de estas prácticas con elementos rituales propios de las religiones vernáculas o, en su defecto, a los restos que habían sobrevivido a la andanada aculturadora de la evangelización católica. Ésta, como ya se ha planteado, al menos para Chile todavía era frágil, y lo seguiría siendo en los años venideros, lo que también incidía en la carencia de control de las costumbres originarias $^{13}$. Lo anterior, en alguna medida lo demostraba la extendida poligamia indígena, principalmente de sus caciques, como se pudo comprobar en la visita hecha en 1579 a las comunidades maulinas de Huenchullami, Loncomilla y Vichuquén. A ello se sumaba que otros tantos (incluso más que los polígamos) declararon que no conocían las oraciones, o que no eran cristianos ${ }^{14}$.

Pero el problema parecía ser más amplio, como puede desprenderse de la probanza de méritos del padre Juan Jufré, sobrino del famoso conquistador y entusiasta

10 Ibídem: 237.

11 Boccara, 2007: 142-170; Foërster, 1993: 16-21.

12 Mariño de Lobera refiriéndose a las campañas del maestre de campo Alonso Bernal del Mercado en la zona de Purén en 1571, indicó que: "salió luego con ellos [su tropa] a correr la tierra haciendo siempre algunas presas, y estando en la República de Unquelemo dio sobre el capitán della, que estaba descuidado en gran borrachera y regocijo [...]" Mariño de Lobera, 1865: 333; En 1596 Diego de Bastidas, relató que: "en el fuerte del Guelpilon llevando engañado con falsa rrelaçion un yndio al maese de canpo Alonso Garçia Ramon y muchos soldados diziendo que en una quebrada estavan descuidados unos yndios en fiestas y que los podrian traer e conquistar llegados que fueron hallaron ser mucha cantidad de yndios que estavan aperçibidos de guerra y con las lanças en las manos salieron con tanto ynpetu que hirieron muchos soldados [...]”. Declaración de Diego de Bastidas en la probanza de servicios del capitán Cristóbal de Morales. Lima, 8-III-1596. AGI, Lima, 211, nº 11, f. 26v; por su parte en 1607 el coronel Pedro Cortés señaló que saliendo del fuerte de Santa Lucía, situado en la orilla sur del río Biobío: "yendo en busca del enemigo dimos en donde estavan en una gran junta e borrachera cantando bitoria del buen suseso y di en ellos al alba e los desbarate e mate muncha gente e se coxieron muchas pieças [...]" Certificación del coronel Pedro Cortés de los servicios del capitán Pedro de Contreras. Santiago de Chile, 28-XI-1607. AGI, Lima, 206, nº 19, f. 8r. Las cursivas son nuestras.

13 Contreras, 2016: 48.

14 Ramón, 1960. 
evangelizador en el obispado de Santiago. En ella destacó su gran manejo de las lenguas indígenas y sobre todo del mapudüngún; su profundo conocimiento de los habitantes originarios y su experiencia de más de seis años como doctrinero en Chile central, en cuyo ejercicio afirmaba haber convertido a gran cantidad de indígenas viejos, quienes eran los más refractarios a recibir el evangelio, pues decían que siendo tan ancianos no tenían necesidad de hacerlo. Asimismo, había discutido con ellos las ventajas del cristianismo y los había reprendido, aduciendo que estos eran engaños del demonio, respecto de "quan mala la yrronia seremonias y rritos que tienen de que usan [...]"15, palabras por las cuales y pesar de su autoafirmado éxito evangelizador, se había visto obligado a reconocer que estas ceremonias y ritos, aun cuando fueran un engaño del príncipe del mal, seguían presentes entre sus obligados feligreses.

Algunos de sus testigos fueron más allá al referirse a las creencias indígenas, y no solo a sus expresiones rituales. Uno de ellos fue el capitán Alonso de Riberos, futuro encomendero de Aconcagua alto. Éste, quien era criollo de Chile y según sus propias palabras los conocía desde niño, afirmó que él mismo: "a visto que los yndios viejos dizen que no ay nesçesidad de ser xripstianos y a muchos a oydo este testigo que quando mueren que sus animas ban a los cerros [...]"16. Estas palabras, casi contemporáneas a la visita citada, en alguna medida ponen en contexto a los visitados en 1579, que afirmaron sin mayores problemas no ser cristianos. Lo anterior, pues esta declaración dejaba implícito (aunque parezca obvio) que tenían una postura religiosa distinta del catolicismo, una que pensaba que los muertos convertidos en espíritus moraban en las montañas; y si bien no es posible afirmar hasta qué punto se habían conservado las creencias religiosas vernáculas en Chile central y el Norte chico, o si estas todavía constituían un sistema articulado de creencias, si se puede plantear que algunos de sus elementos sobrevivían con gran fortaleza a más de treinta años de llegados los castellanos ${ }^{17}$. Ahora bien, ningún fallecido haría este último viaje sin las ceremonias y los especialistas de lo sagrado que las oficiasen, lo que nuevamente dejaba abierta la puerta a la sospecha de que escondidos como hombres o mujeres comunes y corrientes los y las machis siguieran operando, o peor aún, que entre la multitud de los capturados en la guerra y trasladados a Chile central algunos de ellos fueran estos temidos chamanes ${ }^{18}$.

Las fuentes, en tal sentido, parecen ser incapaces de mostrar en toda su dimensión lo que estos actos significaban. Quizás quienes las producían todavía no tomaban real conciencia de que en Chile la composición de la población indígena estaba experimentando un profundo cambio. Éste no decía relación solamente con la disminución de sus habitantes originarios, sino también con la continua llegada de inmigrantes indígenas. Entre ellos se contaban los venidos voluntariamente, de los

15 Probanza de méritos y servicios del padre Juan Jufré, clérigo presbítero. Santiago de Chile, 29-XII-1577. AGI, Chile, 64, sin foliar.

16 Declaración del capitán Alonso de Riberos en la probanza de servicios del padre Juan Jufré. Santiago de Chile, 29-XII-1577. AGI, Chile, 64, sin foliar.

17 Valenzuela indica que la religión mapuche, tronco cultural al que pertenecían los grupos étnicos de Chile central, tenía un sentido preferentemente animista, orientándose al culto de los antepasados y canalizando lo divino hacia las formas y experiencias de la naturaleza. Las almas de los muertos se convertían en pillanes, manteniendo la comunicación con los vivos y conservando injerencia directa en el bienestar o malestar de las personas y se les invocaba con ofrendas de chicha o sangre. Valenzuela, 2012: 205-206.

18 Sobre las machis y su papel chamánico: Bacigalupo, 1995: 52-55. 
que eran mayoritarios los llamados cuzcos peruanos ${ }^{19}$ y los juríes del Tucumán, aunque también había hombres y mujeres de Araucanía, Valdivia y Chiloé ${ }^{20}$. Asimismo, debían sumarse los que eran traídos a la fuerza desde estos últimos territorios y los huarpes de Cuyo, a los que sus encomenderos hacían transmontar la cordillera de los Andes para trabajar en los valles chilenos cisandinos ${ }^{21}$.

Estos migrantes, heterogéneos en sus orígenes y en sus modalidades de asentamiento, estaban cambiando la demografía del país. En el caso de quienes eran trasladados a la fuerza desde el sur del reino, se trataba de hombres y mujeres cuyos procesos de integración a la sociedad colonial y, en particular, de evangelización eran aún más frágiles que los vividos por los de Chile central y el Norte chico. El dominio del castellano, el conocimiento de las oraciones cristianas, la adopción de costumbres e instituciones españolas, podrían ser seriamente cuestionados en estos casos. Aunque en algunas ocasiones se trataba de tributarios de encomiendas penquistas o de la Araucanía ello no significaba mucho, pues desde la fundación de Concepción y de las villas situadas allende el Biobío, con los consiguientes nombramientos de vecinos y encomenderos, la relación de estos con "sus" indígenas había transitado entre el acatamiento y la rebeldía, como bien lo muestra la captura que en 1576 hizo Rodrigo de Quiroga de más de trescientos hombres de la costa de Arauco ${ }^{22}$.

Sospechando una traición de los levos de Arauco y Tucapel, que recientemente le habían dado la paz, el gobernador procedió a su captura, con lo cual entró en un grave conflicto con los encomenderos de la zona, especialmente con doña Marina Ortiz de Gaete, la viuda de Pedro de Valdivia, quienes solicitaron que les fueran devueltos para ser reincorporados a sus repartimientos ${ }^{23}$. Contrario a ello Quiroga ordenó que los caciques fueran trasladados al Perú, mientras que el resto de los presos se llevaran a la jurisdicción de La Serena donde debían ser ocupados en la extracción de oro, metal con que éste pretendía financiar la guerra. Sin embargo, al poco tiempo de llegados allí, y según lo escrito por Juan de Gálvez, su administrador: "se quisieron huir algunos y se prendieron y ahorcaron seis o siete de ellos y se cortaron los pies a otros cincuenta $[\ldots]^{\prime 22}$. Acciones que parecían predecibles, tanto en lo referido a la pretensión de unos de huirse, como al castigo aplicado por los otros, los españoles, en cuya lógica el terror cumplía una función pedagógica, que pretendía hacerle entender al resto de los capturados lo que les esperaba si intentaban algo similar ${ }^{25}$.

Más allá de lo anterior, con ello se concretaba uno de los máximos temores de los castellanos, cual era que tanto la huida como el alzamiento eran acciones posibles al trasladarse prisioneros rebeldes desde los territorios de guerra hacia zonas donde el

19 Valenzuela, 2010.

$20 \quad$ Valenzuela, 2014a y 2014b; Contreras, 2017.

21 Jara 1958; Michielli, 1996: 34-46; Michielli, 2011.

22 Carta del licenciado Melchor de Calderón al rey. Santiago de Chile, 8-IX-1577. Colección de Documentos Inéditos para la historia de Chile (en adelante CDIHCh), $2^{\text {a }}$ serie, t. II, 1957: 332.

23 Respecto de la fragilidad de las encomiendas de Araucanía resultan aclaratorias las palabras del capitán Lorenzo de Figueroa, quien al testar declaró: "que estando en la dicha mi veçindad de Arauco, y de paz mis yndios yo hiçe a credito una pezqueria de tollos que en ellos haçian e me pagaban mi tributo, gaste de la haçienda de Anton Juarez y de sus herederos que me la dio a este credito Alejandro de Candia que seran quatroçientos pesos poco mas o menos...y en este ynterin se alço la tierra declaro ser deudor de lo que paresçiere por la dicha escriptura [...]". Testamento del capitán Lorenzo de Figueroa. Santiago, 9-IX-1605. Archivo Nacional Histórico [Chile] (en adelante ANH), Escribanos de Santiago (en adelante ES), 35 bis, ff. 223-223 vta.

24 Carta de Gregorio Sánchez al virrey don Francisco de Toledo. La Serena, 25-III-1578. CDIHCh. $2^{\mathrm{a}}$ serie, t. II, 1957: 371 .

25 Espino, 2013. 
dominio colonial se suponía asentado. Con ello la "contaminación" de los indígenas locales se volvía perfectamente plausible.

Vigilar sus acciones, controlar sus costumbres, y desestructurar sus sistemas religiosos y políticos eran las acciones que debían seguirse, pues la llegada de prisioneros a los territorios nucleares del reino se convirtió en una realidad extendida e imparable. Las modalidades que adoptaba su arribo eran variadas, y a ello los gobernadores prestaban todo su apoyo, pues a pesar de que la esclavitud estaba prohibida, no faltaban los resquicios para legitimar su presencia. El más recurrido era permitir que los que ya estaban encomendados en Araucanía, pudieran ser llevados a las propiedades que sus feudatarios tenían en Chile central; o bien, en el caso de los capturados en la guerra y con independencia de si eran parte de algún repartimiento o no, condenarlos a muerte y luego conmutar su pena por el extrañamiento. Tal recurso fue usado con mucha frecuencia por el gobernador Alonso de Sotomayor, como se puede apreciar en una cédula de encomienda dictada en 1587, en la cual argumenta que:

Aunque por su rebelion y delitos que an cometido contra el real serbiçio mereçian ser castigados con muerte natural usando de piedad con los dichos yndios el dicho don Luis de Soto Maior mi hermano tubo por bien en comutarles la dicha pena de muerte cibil y destierro perpetuo de su natural para las ciudades de Santiago y de la Serena $[\ldots]^{26}$.

Procediendo a encomendar al menos quince de ellos, entre los que se contaban cinco que ya estaban adscritos a diferentes feudatarios de Valdivia, y otros diez procedentes de la llamada Isla de Nieto de Gaete situada en Osorno, en la persona del capitán Pablo Flores. Éste, cinco meses más tarde, tomó posesión de su encomienda en Santiago, ceremonia a la que se hizo acompañar por seis de sus nuevos tributarios, lo que es muestra evidente de su traslado ${ }^{27}$.

También era posible conseguir que por las necesidades de la guerra el virrey autorizara la deportación de los rebeldes, y su empleo como peones en la extracción de oro para financiar las tropas que combatían en el sur, aunque esto nunca se concretó, pues fueron repartidos a mineros particulares, y a algunos encomenderos serenen$\mathrm{ses}^{28}$. No obstante, tal cuestión llegó a ser refrendada por una real cédula dictada en Madrid el 13 de enero de 1575. Dicho documento, en alguna medida, dio el visto bueno al extrañamiento como método de castigo, pero más aún a la propia captura,

26 Cédula de encomienda del gobernador don Alonso de Sotomayor al capitán Pablo Flores. 20-I-1587. ANH, Real Audiencia (en adelante RA), 751, pza. 6a, f. 164.

27 Entre los muchos casos que podrían citarse, consta que en marzo de 1592 Sotomayor encomendó al capitán Alonso de Córdoba una treintena de indígenas de la isla Mocha, bajo los argumentos de ser de guerra y haberles conmutado la pena de muerte. Tal encomienda incluía a un cacique y su mujer, seis hombres casados y con hijos, y una veintena de solteros, quienes habían pertenecido al repartimiento de Hernando Lamero de Andrada. Córdoba tomó posesión de ellos dos meses más tarde en Santiago. Cédula de encomienda del gobernador Alonso de Sotomayor al capitán Alonso de Córdoba. Fuerte de San Idelfonso, 15-III-1592. AGI, Chile, 43, nº 7 , ff. 181r-181v.; en 1600 consta el traspaso, vía renuncia a la encomienda, de un grupo de indígenas de Gualemo y otros, al parecer, provenientes de Chiloé, del capitán Agustín Briceño al Colegio Máximo de la Compañía de Jesús en Santiago. Dejación de la encomienda del capitán Agustín Briceño al Colegio Máximo de la Compañía de Jesús. Santiago de Chile, 1-VIII-1600. ANH, ES, 27, f. 333.

28 Instrucciones del virrey don Francisco de Toledo a la Real Audiencia de Chile. Lima, 1574. AGI, Patronato Real 227, R. 8, sin foliar; CDIHCh. $2^{\mathrm{a}}$ serie, t. II, 1957: 72. 
asumiendo una realidad dramáticamente presente sin cuestionar el fondo del asunto, que no era solo la legalidad o ilegalidad de la misma, sino los efectos que dichas deportaciones tendrían sobre las sociedades locales ${ }^{29}$.

Lentamente se extendía la presencia de pequeños grupos de inmigrantes forzosos, y de algunos voluntarios, en las ciudades de La Serena y Santiago, o trabajando en las minas, estancias y obrajes situados desde los valles maulinos hasta el Norte chico $^{30}$. Consecuentemente con aquello, en las fuentes se percibe una expansión de la preocupación por la ocurrencia de juntas y reuniones signadas por el consumo de alcohol; la presencia de asaltantes indígenas en los campos, a la vez que se resucita la persecución de envenenadores y hechiceros, aunque ahora la coyuntura era distinta a veinte años atrás. En tal sentido, la presencia mapuche se hacía sentir fuertemente, y aquellas actividades que habían sido planteadas como una derivación delincuencial o inorgánica de las sociedades indígenas sometidas de Chile central, en este nuevo contexto, ya empezaban a incluir a la rebeldía como elemento a considerar.

Esto se expresa bien en las órdenes impartidas por el gobernador Rodrigo de Quiroga en 1576 cuando, luego de dos nombramientos fracasados, encargó al capitán Pedro Lísperguer que se ocupara de perseguir los hechiceros que, según él, abundaban en los parajes situados entre los valles de Cachapoal y Maule. Dicho mandamiento incluyó un acápite dirigido especialmente a impedir la realización de las borracheras "que hacen en general los indios deste distrito [...]"31, y otro en que le ordenó estar atento a la existencia de salteadores y alzados. Era ésta la primera vez que tales posibilidades se planteaban con algún viso de realidad pues, aunque se basaban en informaciones llegadas desde los territorios supuestamente afectados, no se entregaron mayores detalles sobre ello, aunque insistió en nombrar un juez de comisión.

Sin embargo, no será hasta cinco años después en que las Actas del Cabildo de Santiago, que en el intertanto habían reiterado la prohibición de rescatar vino en las minas $^{32}$, y hecho cumplir la orden del gobernador de decepar los higuerales y viñas de la Chimba, se preocuparán con cierto detalle de las borracheras ${ }^{33}$. Nuevamente tales Actas ofrecen más bien pistas que certezas, algunas de las cuales pueden resultar equívocas, pues el lenguaje empleado se presta para asignarle ciertas interpretaciones que no resultan siempre las más adecuadas. Sobre todo gracias al uso de términos derivados del quechua, lo que no significa necesariamente que la filiación cultural de las actividades descritas tengan relación con la religiosidad andina, aunque ello tampoco puede descartarse a priori ${ }^{34}$. Lo importante, en este caso, es que los ediles identificaban -aunque en una obvia visión negativa- las borracheras que se desarrollaban en el contexto de matrimonios y otras celebraciones, como eventos que servían para idolatrar, adorar a las wakas, y apostatar en el caso de los que eran

29 Real Cédula para que no se maten ni destronquen los indios tomados en la guerra, sino que se destierren y se hagan mitimaes. Madrid, 13-I-1575, ANH, Cabildo de Santiago, 55, f. 77 vta.

30 Contreras, 2017: 161-196.

31 Comisión del gobernador Rodrigo de Quiroga para castigar a los indios hechiceros. Santiago de Chile, 22-XII1575. CHCh, t. XVII, 1898: 429-431.

32 Auto sobre el rescate de oro por vino en las minas. Santiago de Chile, 17-X-1578. CHCh, t. XVII, 1898 : 60. Esta disposición se refiere a la prohibición de que los españoles trocaran vino por oro a los peones indígenas que trabajaban en los lavaderos de Chile central.

33 Mandamiento del gobernador Rodrigo de Quiroga sobre que se decepen las viñas e higuerales de la Chimba. Santiago de Chile, 3-VII-1579, CHCh, t. XVIII, 1899: 291-292.

34 Contreras, 2016: 48-49. 
cristianos, además de que allí se cometían incestos y asesinatos. No obstante, lo que interesa destacar es que por una parte se reconocía implícitamente que los idólatras y adoradores de wakas no eran cristianos, y que quienes habían adoptado el cristianismo apostataban ${ }^{35}$.

Vuelve a surgir la pregunta y su posible respuesta: ¿Quiénes, sino los indígenas capturados en la guerra y quizás también los tributarios de encomiendas más lejanas a Santiago, como los de Maule, eran los paganos? O bien ¿hasta qué punto había avanzado el proceso de cristianización que con tanta facilidad afloraban estas representaciones? Más allá de los prejuicios de autoridades y funcionarios, lo cierto es que la evangelización era tan precaria como fuerte se hacía la presencia de migrantes forzosos entre los indígenas del centro y el Norte chico, más aún cuando para fines del siglo XVI el proceso de despueble de las comunidades originarias encomendadas no daba paso atrás.

Ante esto había que actuar en dos frentes. Por una parte, los esfuerzos catequísticos debían aumentar y, en tal sentido, la llegada de los jesuitas en 1593 y la fundación de conventos y monasterios de otras órdenes, como franciscanos y mercedarios, eran parte de la preocupación por llevar la palabra cristiana a los habitantes de la Araucanía (la que, al menos, era predicada a los yanaconas de las ciudades del sur), a los escasos encomendados mapuches y a los naturales de Chile central, donde la cristianización había sido un proceso frágil y entregado al arbitrio de unos cuantos clérigos seculares e, incluso, de algunos laicos. Por otra, se debía estar siempre vigilante frente a todas aquellas actividades, como las borracheras, que resultaban masivas, y campos propicios para la juerga y el descontrol etílico, pero también para adorar a los antiguos espíritus tutelares. Por ello no es de extrañar que el Cabildo intensificara la vigilancia de estas actividades, incluso al nombrar funcionarios que en principio no tenían mucho que ver con el asunto, como un juez de aguas; pero que si eran quienes acudían a las estancias y pueblos indígenas a verificar la distribución del vital líquido, lo que les permitía observar directamente lo que pasaba en cada lugar ${ }^{36}$.

$\mathrm{Si}$ a lo anterior se suma que en los últimos años de la centuria Chile se vio afectado por al menos dos epidemias, una de ellas de sarampión y otra del llamado tabardillo, lo que redundó en una disminución todavía mayor de la población originaria, y aunque ciertamente se incluían los migrantes forzosos, estos nunca dejaron de llegar a estos territorios, aumentando su participación porcentual y cultural entre los indígenas. De ahí entonces que, al momento de producirse el alzamiento de 1598, la posibilidad de que hubiera sospechas de violencia rebelde al interior de Chile no

35 Hemos publicado las órdenes y bandos que dicen relación con borracheras e intentos rebeldes en Contreras, 2014.

36 Desde 1576 en adelante y hasta principios del siglo XVII constan en Actas que el Cabildo de Santiago trató o tomó alguna medida respecto de las borracheras indígenas en: Acta del cabildo del 9 de agosto de 1576. Santiago de Chile, 9-VIII-1576. CHCh, t. XVII, 1898: 454; Acta del cabildo del 17 de julio de 1579. Santiago de Chile, 17-VII-1579. CHCh, t. XVIII, 1899: 123-124; Acta del cabildo del 10 de junio de 158., Santiago de Chile, 10-VI-1580. CHCh, t. XVIII, 1899: 208; Acta del cabildo del 27 de octubre de 1581. Santiago de Chile, 27-X-1581. CHCh, t. XVIII, 1899: 337; Acta del cabildo del 3 de julio de 1584. Santiago de Chile, 3-VII-1584. CHCh, t. XIX, 1899: 203-204; Acta del cabildo del 4 de noviembre de 1588. Santiago de Chile, 4-XI-1588. CHCh, t. XX, 1900: 183; Acta del cabildo del 3 de febrero de 1589. Santiago de Chile, 3-II-1589. CHCh, t. XX, 1900: 199; Acta del cabildo del 18 de enero de 1591. Santiago de Chile, 18-I-1591. CHCh, t. XX, 1900: 302303; Acta del cabildo del 4 de enero de 1593. Santiago de Chile, 4-I-1593. CHCh, t. XX, 1900: 426; Acta del cabildo del 30 de mayo de 1603. Santiago de Chile, 30-V-1603. CHCh, t. XXI, 1900: 21; Acta del cabildo del 6 de abril de 1604, Santiago de Chile, 6-IV-1604. CHCh, t. XXI, 1900: 109. 
eran excluibles. En ese contexto, de derrotas militares, pérdida de vidas y tierras, de cautiverio y destrucción de ciudades, es que la guerra pareció trasladarse clandestinamente más allá del sur del reino para llegar a las inmediaciones de la capital.

Desde hacía ya unas décadas Chile central y el Norte chico habían visto como los capturados en la guerra eran distribuidos por chacras y estancias, las mismas que los eclesiásticos consideraban los peores lugares para evangelizar, pues quedaban distantes de doctrinas y conventos. Además, muchas de ellas estaban alejadas de los caminos principales que salían tanto al norte como al sur de Santiago, o el que llevaba al puerto de Valparaíso. Éstos eran lugares perfectos para rebelarse, y sobre los cuales se centraron los rumores que volvieron a tomarse las calles de la capital, los que esta vez llegaron directamente a oídos de su corregidor. Éste, como se citó al principio de este artículo, prontamente identificó a los supuestos alzados y tras una rápida indagatoria "hiço castigo ahorcando los mas culpados por lo qual se asiguro y sosego la tierra [...]", lo que luego se repitió en Santiago, donde los cabecillas de la conspiración fueron colgados ${ }^{37}$.

No era la primera vez que los santiaguinos veían indígenas ejecutados en la plaza mayor. En tal sentido, no está de más recordar que cincuenta años antes la cabeza del rebelde toki Lautaro había sido exhibida en el mismo lugar; sin embargo, si era la primera oportunidad en que los ajusticiados eran habitantes de la ciudad, o de los territorios situados inmediatamente al norte de ella. Con esto, se hacía carne el temor hispano a esta suerte de enemigo interno, inserto dentro de sus propios territorios e inidentificable en lo cotidiano, el que podía enseñorearse de amplios valles y de la propia ciudad, si es que no era detenido a tiempo. A ojos de los españoles también demostraba que la comunicación entre los cautivos indígenas, los originarios del Norte chico y Chile central, y aquellos que seguían habitando los territorios de Penco y Araucanía nunca se había cortado. Para los hombres de la época ello implicaba no solo intercambio de información, sino también una posible coordinación conspirativa. Pero el problema era más complejo, pues la llegada de migrantes mapuches forzosos significaba un continuo intercambio de bienes culturales inmateriales, entre los que se contaba el reforzamiento idiomático, y la continuación de la adoración a los pillanes, muchos de los cuales parecían hacerse presentes en las borracheras.

\section{Tiempos rebeldes, migración forzosa y juegos de chueca}

Fáltanles el servicio de los indios, pues muchos de los que antes les servían como fieles y leales aora hurtan y roban, acometiendo y emprendiendo otras mil malda$\operatorname{des}[\ldots]^{38}$.

Así se refería la Carta Annua de la provincia jesuita del Perú a la situación por la que pasaban los vecinos de las ciudades chilenas de La Serena y Santiago en 1602. Estas eran las únicas que estaban en condiciones de aportar con hombres, víveres y

\footnotetext{
37 Información de méritos y servicios del capitán Jerónimo de Molina. Santiago de Chile, 18-XI 1610. AGI, Chile, 34 , sin foliar.

38 Fernández, S. J., 1986: 300-301.
} 
dinero para combatir al enemigo indígena alzado en Penco y Araucanía, el que no solo había terminado con la vida del gobernador Martín García Oñez de Loyola, sino que había asolado las villas del sur del reino, algunas de las cuales fueron reducidas a cenizas; mientras que otras estaban cercadas, sumiendo a sus habitantes en el miedo y la carestía. Sin embargo, ello no era lo único que esta rebelión había logrado. En las llamadas tierras de paz parecía que los indígenas de servicio habían aprovechado el impacto de la guerra, el pequeño número de españoles que habitaban Chile, y la sensación de descontrol alimentada por las constantes noticias de derrotas, para delinquir y negarse a trabajar.

En la medida que el control ejercido por corregidores y cabildos tendía a hacerse más laxo, se podría hipotetizar, los indígenas se sentían con mayor libertad para volver a sus costumbres bárbaras (como lo dirían los españoles), armarse y saltear los caminos. No obstante, para la época no se ha conservado ninguna denuncia ante las justicias del reino por hechos similares, y casi no hay fuentes que refrenden lo planteado por el redactor de la Carta Annua. Probablemente éste interpretó tales hechos a partir de las informaciones que le hicieron llegar sus hermanos de Chile. ¿Significaba aquello que se estaba frente a un embuste o a una interpretación exagerada de las noticias llegadas desde el austral reino a Lima? O en su defecto, aparte de dar cuenta de lo sucedido, estas palabras traducían bien la inseguridad, quizás el miedo, y muy probablemente la profunda desconfianza que los españoles sentían por los indígenas.

Más aun cuando los migrantes forzosos mapuches, legalmente libres aun cuando hubieran sido cogidos en la guerra, se confundían entre sus congéneres de Chile central y como ellos, al menos algunos, podían trasladarse por campos y caminos. ¿Qué diferenciaba exteriormente a éstos de quienes se desplazaban de manera voluntaria, o aun de los habitantes originarios de los valles centrales? Nada muy evidente. Por lo cual la desconfianza española se constituía como un sentimiento permanente, y que salía a relucir con fuerza en coyunturas críticas, concretamente a través del aumento de la vigilancia en los extensos parajes de los corregimientos cercanos a Santiago, y en la propia ciudad. En ella el Cabildo se mostraba atento a normar cualquier actividad que considerara permisiva, aunque no fuera ilegal.

En diciembre de 1606, en un contexto en que el alzamiento había bajado su intensidad, se había fundado un Ejército, y se comenzaba a constituir una frontera, el teniente general del reino logró aprobar en Cabildo Abierto un conjunto de medidas que aumentaban el control en el campo y en la urbe. Junto con la consabida prohibición de las borracheras, se implementó una férrea vigilancia a los indígenas, los cuales debían ser empadronados para conocer quiénes eran y dónde se asentaban; asimismo, se limitaron fuertemente sus desplazamientos y se instruyó a corregidores, estancieros y administradores de pueblos de indios, que donde éstos vivieren:

busquen si tienen armas de cualquier suerte que sean y se las quiten, y al que las trujere ocultas o públicas, cualquier español se las pueda quitar, y los traigan presos al corregidor de partido o ciudad, los cuales castiguen los delitos con mucho rigor $[\ldots]^{39}$.

39 Acta del Cabildo de Santiago del 19 de diciembre de 1606. Santiago de Chile, 19-XII-1606. CHCh, t. XXI, 1900: 357 . 
Medidas que, probablemente, se fundaban en la noción de que era imposible estar seguros de que los focos rebeldes descubiertos por el capitán Jerónimo de Molina fueran los únicos existentes. Tampoco se podía tener certeza que la flecha de la guerra no corriera por los campos de Chile central. Considerando que ésta debía ser llevada en secreto, se buscaba controlar cualquier desplazamiento indígena, más aún si era de aquellos que, en esta oportunidad, se identificaron como "forasteros". Asimismo, se ordenó hacer rondas por la ciudad y sus alrededores:

haciendo en esto las diligencias necesarias para inquirir y saber dónde hay juntas o borracheras, y los que ansí rondaren tengan comisión para deshacerlas y prender a los que anduvieren por la ciudad, en especial negros, mulatos e indios, y los que destos se toparen se traigan a la cárcel, donde serán rigurosamente castigados $[\ldots]^{40}$.

Aquí la identificación de las borracheras o juntas (palabra usada con frecuencia para referirse a las concentraciones de guerreros) con la rebeldía era directa. Tales juntas se constituían en un espacio privilegiado para planear el alzamiento, y como se ha visto más arriba, para reavivar los ritos y ceremonias nativas; cuestiones que se hacían urgentes de frenar, aunque esta era una tarea compleja sobre todo cuando en las cercanías de Santiago la producción de vino era abundante ${ }^{41}$. Éste, a su vez, se vendía en las pulperías repartidas por toda la ciudad, muchas de las cuales eran atendidas por indígenas, negros, o mulatos ${ }^{42}$. A este respecto, el Cabildo capitalino estaba atrapado en una profunda tensión entre la necesidad de abastecer a sus habitantes de lo necesario para la subsistencia, y los problemas que causaba la existencia de estos establecimientos. Ya en 1604 había decidido prohibirlas, argumentando que gracias a ellas negros e indígenas se habían convertido en viciosos, drama que también afectaba a los jóvenes de la elite, quienes si eran estudiantes vendían sus libros, mientras que los esclavos hurtaban los bienes de sus amos para cambiarlos por alcohol ${ }^{43}$.

Más allá de la coyuntura referida cada día entraban y salían de Santiago numerosos indígenas con productos que debían entregar en las casas de sus encomenderos, u otros que traían para ser vendidos. Estos podían llevar de vuelta en sus propias carretas el mosto necesario para sus borracheras, más aún en una sociedad como la chilena donde la moneda escaseaba, y en la cual las transacciones se valorizaban en dinero, pero se pagaban en especies. Los pulperos, por su parte, no tenían inconvenientes en recibir productos agrícolas para revender, y pagarlos con alcohol ${ }^{44}$. Esto

40 Ibídem.

41 Para la década de 1550 ya se consigna la producción de vino en los extramuros de Santiago. Éste era producido por propietarios españoles empleando indígenas como peones y viñateros. Ruiz, 2006: 58-60. Sobre la producción vinífera en Chile central durante el siglo XVI: Muñoz, 2014 y 2006.

42 Entre otros: Asiento de trabajo de Juan, indio, natural de Santiago del Estero, con Juan Crespo, pulpero. Santiago de Chile, 31-I-1611. ANH, ES, 41, ff. 23-23 vta.; Asiento de trabajo de Francisco, indio, natural de la provincia de los Juríes con Antonio de Orihuela, pulpero. Santiago de Chile, 8-IX-1612. ANH, ES, 50, f. 62; Asiento de trabajo de María, india, natural de la ciudad de Concepción con Antonio Hernández, pulpero. Santiago de Chile, 13-III-1625. ANH, ES, 106, f. 241.

43 Acta del Cabildo de Santiago de 7 de mayo de 1604. Santiago de Chile, 7-V-1604. CHCh, t. XXI, $1900: 113$.

44 Véase, a modo de ejemplo, el Acta del Cabildo de Santiago de 6 de septiembre de 1566, que hace referencia a la forma en que debía efectuarse en la ciudad el tráfico de carretas conducidas por indígenas. Santiago de Chile, 6-IX-1566. CHCh, t. XVII, 1898: 114. 
empeoraba si las pulperías se instalaban en los sectores rurales, aunque sus dueños fueran españoles de elite, como sucedió en 1633 con la que abrió don Diego de Rivadeneira en el valle de Quillota la que, además, era atendida por uno de sus esclavos negros. Éste fue denunciado ante la Real Audiencia por vender vino y otros productos, como los hilos de acarreto y de coser, a precios excesivos. Pero peor aún, pues: "los yndios se mataban y ellos y los negros hurtaban lo que podian para llebar a la dicha pulpería [... $]^{345}$. Lo que redundaba tanto en el alza de los robos en el valle, como en la ausencia de los peones de sus labores en cualquier momento del año, y no solo en los días festivos, que eran los escogidos para hacer las borracheras.

Ello no dejaba de tener importancia si se considera que el valle de Quillota, así como los que se situaban en sus lindes, habían sido el escenario del frustrado alzamiento descubierto por Molina. Mientras tanto, en 1613 se denunció la presencia de una banda de salteadores indígenas, quienes se dedicaban a asaltar a los transeúntes armados con lanzas y cuchillos. Ante ello la Real Audiencia nominó a dos destacados vecinos del valle y ex oficiales del Ejército de la Frontera para que formaran tropas, y los persiguieran. Uno de ellos, el capitán Martín de Santander, preguntó a los testigos de su probanza de méritos si les constaba la orden que tuvo para ir:

al castigo de [las] tropas de indios simarrones que tubieron nueba andaban en aquella comarca y estançias de su distrito salteando y asiendo daño y si saben que en cumplimiento de lo que se le mando lebanto la gente que pudo y peleo con ella y corrio toda aquella comarca y auyento los dichos simarrones y castigo los culpados $[\ldots]^{46}$.

Méritos que hizo valer ante el Consejo de Indias una década más tarde, pero que traducían bien los niveles de inseguridad que se podían vivir en los sectores rurales, aunque fueran episódicos ${ }^{47}$. Sin embargo, aunque se intentara limitar el desplazamiento de los indígenas, se había demostrado que a menos que se llegara a situaciones extremas (donde se debía intervenir con gente armada), la ocurrencia de juntas alcohólicas seguía siendo un inconveniente. Esste, si bien parecía de baja intensidad, estaba siempre presente y, en ocasiones, al combinarse con otros hechos, estallaba en pequeñas crisis. A estas anomalías habría que sumar un nuevo elemento: la penetración entre los habitantes originarios de los parajes rurales o, quizás habría que decir el resurgimiento, del palín o juego de chueca ${ }^{48}$. Ya en 1626 en el Sínodo de Santiago,

45 Real Provisión para que don Diego de Rivadeneira no tenga pulpería en el valle de Quillota. Santiago de Chile, 17-VIII-1633. ANH, RA, 3027, f. 187.

46 Probanza del capitán Martín de Santander. Santiago de Chile, 16-IX-1624. AGI, Chile, 43, nº 8, f. 5 r.

47 En 1632 el gobernador Francisco Laso de la Vega ordenó al capitán Cristóbal Hernández Pizarro que armara una partida de españoles para capturar 15 aucas que habían escapado del San Bernabé, un barco que frecuentemente transportaba esclavos indígenas. Dicha orden se dio no solo por frenar la huida, sino para evitar que los fugados "se fuesen a sus tierras y diesen notiçia al henemigo rebelde de nuestras fuerzas en este reyno [...]" Probanza de méritos y servicios del maestro de campo general don Cristóbal Hernández Pizarro. Santiago de Chile, 8-I-1652. AGI, 47, $\mathrm{n}^{\circ} 7$, f. 53v.

48 López describe la versión moderna de esta actividad como: "juego mapuche entre dos equipos de 15 jugadores cada uno que forman dos hileras frente a frente en el tercio central de la cancha de un máximo de 200 metros de largo por 12 metros de ancho. Cada equipo consta de un jugador centro, siete atacantes y siete defensores. Golpean una bola de madera de 5 centímetros de diámetro con las curvaturas de sus bastones de madera de aproximadamente 1,20 metros de largo, tomados con ambas manos en oposición, como en el hockey y el golf. [...]". López, 2009: 91. 
que mostraba una preocupación central por la evangelización, se instaba a los visitadores del obispado, a los curas párrocos y a los doctrineros para que velaran por el correcto ejercicio de los actos rituales y los sacramentos, pero también por traspasar su conocimiento de Dios a los indígenas, pues esta era la única manera de combatir aquel enemigo invisible que era, en sus palabras, la idolatría.

Las constituciones sinodales se extendían al describir las distintas maneras en que se burlaba la ortodoxia, refiriéndose en general, pero con mucho mayor conocimiento que las autoridades seculares, a prácticas como el uso de yerbas para curar o matar, las que eran administradas por machis que habitaban entre los indígenas del obispado. Ello, necesariamente, hace retrotraerse a siete décadas atrás cuando las fuentes se referían a los hambicamayos, a quienes designaban como envenenadores que pululaban por el país de los promaucaes, provocando la muerte a pedido ${ }^{49}$. Como resultaba previsible esperar, estas prácticas debían prohibirse, sin embargo, en la perspectiva del Sínodo dichas reuniones iban mucho más allá de simples juergas masivas, pues los:

juegos de chueca, que los naturales de este reino llaman palines, en los cuales hacen muchas idolatrías, invocando al demonio la noche antes y hablando con él y ofreciéndole cosas para que les haga ganar, usando de muchas ceremonias diabólicas con la bola con que han de jugar, y adorando y reverenciando al demonio con reverencia sola debida a Dios $[\ldots]^{50}$.

A lo cual seguía que, luego de terminado este encuentro, se organizaban grandes borracheras, en las que participaban hombres y mujeres, y en donde el consumo masivo de alcohol daba paso a la lujuria, a prácticas sexuales consideradas aberrantes y a la violencia, de lo cual resultaban muertos y heridos. Esto era una narración clásica de las llamadas borracheras, en la cual tanto las autoridades laicas como eclesiásticas de Chile y de otros reinos indianos parecían estar explícitamente de acuerdo. Sin embargo, el palín no era solo un juego, como bien lo planteó el jesuita Diego de Rosales, sino también un entrenamiento para la guerra ${ }^{51}$. Al menos en los asentamientos fronterizos, y en aquellos situados más allá de la ribera sur del río Biobío, era practicado por sus habitantes desde niños ${ }^{52}$. En él se desarrollaban la fuerza, la coordinación corporal, la puntería y el uso de herramientas (en este caso el palo curvo que a modo de bastón servía para dirigir, empujar y proyectar la bola por el campo de palín), así como el trabajo en equipo. Aún más, el propio Rosales argumentó que, en el caso de los mapuches de Araucanía, era de donde resultaban los alzamientos, pues no solo se juntaban gran cantidad de personas en torno al juego y a la borrachera, sino que estos se hacían en lugares apartados, destinados especialmente para ello,

49 Una discusión más amplia sobre las representaciones negativas de los términos hampi y hambicamayo, que en principio dicen relación con la sanación y con quienes la administraban, en: Contreras, 2016: 49 y 51.

50 Oviedo, 1964: 335. Cap. III, Constitución I.

51 Sobre las prohibiciones del "juego de chueca" durante el periodo colonial en una perspectiva diacrónica y descriptiva: López, 2009: 91-117.

52 En tal sentido Rosales argumenta que los indígenas de guerra: "Desde niños se crian en el trabaxo y se exercitan en luchar, saltar, correr y hazer pruebas de fuerzas, y lo principal, en jugar la lanza y disparar flechas, y sus juegos son para ese exercicio, como el de la chueca, que todo es correr tras una vola que lleban de unas partes a otras a porfia con unos como mazos". Rosales, 1877, t. I: 118. 
y muchas veces situados cerca de las tumbas de sus lonkos, lugares donde se podía hablar sin interrupciones ${ }^{53}$.

Por su parte el Sínodo no dejaba ahí su lectura de los indígenas que habitaban el obispado, pues junto con describir sus prácticas e instar a los eclesiásticos a combatirlas, intentaba buscar una explicación a las mismas. Sobre todo pues eran largas las décadas en que los castellanos se habían asentado en Chile, y la jurisdicción santiaguina era la más intensamente ocupada ellos, aunque esto parecía no decir mucho, pues en el propio Sínodo se manifiesta lo alejados que los españoles se encontraban de las prácticas y la moral cristiana, particularmente los que vivían rodeados de indígenas en los campos. Ellos eran caracterizados como amancebados consuetudinarios, y padres de numerosos hijos naturales y mestizos.

En tales términos, las conclusiones a las que se llegó se pueden resumir en que las carencias morales de los indígenas se derivaban fundamentalmente del aislamiento en que la mayoría vivía, al estar asentados en pequeños grupos en las estancias. En ellas la carencia de atención evangélica se hacía sentir, pues si de una parte a los doctrineros no les alcanzaban ni el tiempo ni las fuerzas para atenderlos adecuadamente; de otra, a los estancieros poco les importaba que en sus propiedades hubiera la infraestructura mínima para decir misa, o que muchas capillas estuvieran derruidas, y despojadas de ornamentos para el culto. Peor todavía, algunos pulperos iban a donde se realizaban palines, en los cuales "venden vino a los dichos indios en cantidad que pueden hacer con el borracheras, y muchas veces en ellas sus idolatrías son causa de grandísimos pecados y delitos [...]" "54. Con ello se cerraba un circulo, al menos desde el punto de vista argumental, pues si por un lado estaban los indígenas como grandes consumidores de alcohol, lujuriosos e inmorales; de otro se encontraban quienes los proveían de la bebida, que no eran más que los dueños de viñas y los pulperos, entre los que podía haber tanto españoles como indígenas. Estos, movidos solo por sus intereses personales, eran capaces de subvertir cualquier norma y llamar al peligro que significaba o, mejor dicho, era significado como una posibilidad de que tales encuentros sirvieran para planear revueltas o alzamientos.

Las constituciones del Sínodo describían las prácticas adivinatorias y festivas de los indígenas considerándolas pecados, aunque despojándolas casi totalmente de su carácter ritual y político. Al leerse estas disposiciones pareciera que el tiempo volviera a las décadas centrales del siglo XVI, en las que las borracheras y las hechicerías eran interpretadas solo como actividades de carácter anómico o delincuencial. No obstante, en las constituciones se usaron términos específicos como palín, machi y guecuve para describir ciertas actividades y personas, los que permiten pensar no solo en un mayor conocimiento de los eclesiásticos sobre los indígenas, sino principalmente en que la huella de los migrantes forzosos de la Araucanía, muchos de los cuales eran mujeres, se hacía notar con fuerza en la reintroducción de fonemas, costumbres y rituales entre los indígenas de Chile central. Estos últimos no solo habitaban junto a ellos, sino que se les unían parentalmente y concebían hijos, con lo cual al cabo de unos años se hacía muy complejo determinar tanto los orígenes como las dependencias legales de los que habitaban el medio rural ${ }^{55}$.

\footnotetext{
Ibídem: 118.

Oviedo 1964: 337. Cap. III, Constitución VI.

55 Sobre el asentamiento de esclavos indígenas en Chile central durante el siglo XVII y la creación de vínculos familiares: Valenzuela, 2014b; Muñoz, 2003. Para un proceso similar en los esclavos africanos: Zúñiga, 2010.
} 
Al mismo tiempo, si bien el Sínodo presentaba a indígenas y a negros como "menos capaces" que los españoles para recibir el evangelio, implícitamente reconocía que los primeros tenían un conjunto de creencias propias y especialistas en lo sagrado, como las machis, que les permitían conectarse a través de rituales y ceremonias con sus "demonios". Ello apuntaba a reconocer, aunque a regañadientes, la posibilidad de que entre ellos hubiera una contrapropuesta religiosa que había que anular para llevar adelante la evangelización. Probablemente, y a modo de hipótesis, eran precisamente los contactos cotidianos entre los originarios de los valles centrales y los migrantes forzosos, lo que había posibilitado que las borracheras, los juegos de chueca y las prácticas mágicas se hubieran vuelto a enseñorear de los parajes del reino, ya no solo como juergas difíciles de controlar, sino como complejas actividades donde lo ritual, lo político y, en ocasiones, lo militar se desplegaban en medio de la alerta de las autoridades y la preocupación de la mayoría de los españoles.

Dado lo anterior, la preocupación se hacía presente cada día más, pues si en alguna medida el calendario ritual cristiano marcaba ciertas fechas, como la Pascua de Resurrección, que se volvían especiales para organizar borracheras; en otra, las ocasiones para celebrar estas reuniones no parecían tener un patrón, lo cual hacía más complejo el problema, pues tampoco se podía anticipar la vigilancia sobre todo en los extensos parajes rurales. Se hacía necesario actualizar las órdenes a los funcionarios de justicia. Estas nacían no solo de la conciencia de que estas actividades existían, y llegaban a ser frecuentes; sino que de otros factores, como era la situación militar fronteriza en que cada hecho violento repercutía en los valles centrales chilenos, reavivando la pregunta por la concertación rebelde y clandestina entre ambos territorios. De ahí entonces que, en 1628, la Real Audiencia de Santiago ordenó al alcalde de la Santa Hermandad don Antonio Fernández Caballero que persiguiera los juegos de chueca y las borracheras, haciendo (ahora sin ambages) una lectura política de estos eventos. Así, se consideraba:

que los yndios de Maule y los de açia Coquinbo haçian juntas y conbocasiones para jugar el juego de la chueca y que en ellas tratavan muchas cossas prohividas y cometian muchos exsessos y pecados y haçian grandes borracheras faltando muchos dias del servisio de sus amos de que resultavan muchos ynconvenientes y graves $[\ldots]^{56}$.

Era la primera vez que el problema dejaba de estar radicado en un lugar en particular, como podrían ser las inmediaciones de la capital o el valle del Maule, para plantear que era una situación que involucraba a todo el reino. Esto, que bien podría deberse a una exageración, o a una lectura apresurada a la vez que generalizadora, más bien era un diagnóstico que hacía imperativo el estar alerta, pues el alzamiento estaba siempre latente y al menos una vez antes había estallado al norte de Santiago, lo que demostraba su factibilidad. En una situación frágil, y en una sociedad dispuesta a escuchar rumores, estos pronto se convertían en certezas. Un enemigo interno (una quinta columna) a retaguardia era lo que más se debía temer. Si no como explicar la extensa movilización militar de 1630.

56 Real Provisión para que el alcalde de la Santa Hermandad Antonio Fernández Caballero no consienta las borracheras ni los juegos de chueca de los indios. Santiago de Chile, 3-III-1628. ANH, RA, 3027, ff. 56-56 vta. 
En tal oportunidad las informaciones indicaban que una fuerza rebelde compuesta de más de dos mil guerreros indígenas se movilizaba por las pampas cuyanas para salir desde los contrafuertes cordilleranos al valle de Cachapoal, situado a unos 90 kilómetros al sur de Santiago, y atacar la capital. Ante ello el gobernador le ordenó al corregidor de la ciudad que movilizara al batallón de milicias (las llamadas compañías del número) hacia el lugar del posible surgimiento del campo rebelde. Su fin era enfrentar a un enemigo que nunca llegó y, peor aún, que jamás existió. Pero ello no obstó para que por más de dos meses varias decenas de hombres, entre los que se contaban encomenderos, mercaderes, artesanos y algunos ex soldados, tuvieran que abandonar todo para montar guardia, dejando a la ciudad desguarnecida y según el capitán Sebastián Sánchez, ex alcalde de Santiago, "sola y serca de angustias [...]"57.

Esta movilización frustrada mostró cuan poderosos eran los rumores, pero también hasta dónde se extendían las percepciones de una invasión, y el miedo a un otro desconocido, las que iban mucho más allá de la propia frontera y se acercaban peligrosamente a Santiago. La idea que a esta columna se le unieran los indígenas locales estaba insistentemente presente, y esto hacía más urgente reprimir las borracheras: Dicha tarea le cabía sobre todo a los corregidores, como se puede apreciar en la residencia del capitán Agustín Ramírez, que servía en Colchagua, quien destacó su preocupación por deshacer los amancebamientos y otros hechos calificados como "pecados públicos" y en lograr el bienestar de los indígenas, como se explayaron los testigos, uno de los cuales afirmó que Ramírez:

a acudido con muchas beras y çelo de que se aga el servicio de Dios y el Rey bisitando con mucho cuydado las estancias y pueblo de Rapel procurando con todo cuidado ebitar las borracheras y juegos de chueca y en los que a abido alladose presente por obiar escandalo $[\ldots]^{58}$.

Rapel, junto con Melipilla y Pomaire, eran los asentamientos que proveían de parte importante de la mano de obra del sector poniente y sur poniente del valle de Melipilla, en el cual se encontraba el Obraje del rey, el que con altos y bajos se constituiría en uno de los pocos lugares de concentración indígena de Chile central y en donde décadas más tarde también se testimoniarían la ocurrencia de borracheras ${ }^{59}$.

Aquello, como proyección al futuro no dejaba de tener importancia, pues en la medianía del siglo XVII los eclesiásticos seguían argumentando que era la dispersión indígena por las estancias uno de las principales razones de su falta de doctrina. Esto lo dejaron meridianamente claro los religiosos que, a instancias del metropolitano de Santiago, dieron su testimonio en los autos que se levantaron sobre elevar la congrua de los curas evangelizadores. Lo que más se repetía era que los indígenas no sabían persignarse ni rezar, que en sus casas no había imágenes sagradas, y que su asistencia a misa era muy escasa; que eran grandes aficionados a la embriaguez y a juntarse en borracheras, donde sucedían muertes y otros graves pecados relacionados con el sexo. Pero incluso en ellas había distinciones, como lo expresó en 1642 el licenciado

57 Declaración del capitán Sebastián Sánchez Chaparro en la probanza del maestro de campo general don Cristóbal Hernández Pizarro. Santiago de Chile, 15-I-1652. AGI, Chile, 47, nº 7, f. 161v.

58 Testimonio del capitán Lorenzo Núñez y Silva en el juicio de residencia del corregidor de Colchagua don Agustín Ramírez. Nancagua, 26-IV-1637. ANH, RA, 1210, pza. 4ª, f. 268 vta.

59 Autos de las visitas a los indios de Melipilla. Melipilla, 2-I-1679. ANH, RA, 1589, pza. 2a, f. 204. 
Luis Toledo, un doctrinero secular, quien planteó que junto a las borracheras que se organizaban por un matrimonio u otra celebración familiar, había otras que llamó "generales", en las cuales se reunían:

de dos mil y tres mil almas que an durado diez o doçe dias y no tener en todo este tiempo mas ejerçiçio que cantar baylar y beber hasta privarse de sus sentidos y en las ordinarias que no son generales se matan a cada passo como bestias y como gente sin Dios sin sacramentos y sin notiçia del sancto evangelio $[\ldots]^{60}$.

Estas declaraciones llevan a preguntarse si lo anterior era posible, dado la gran dispersión de los indígenas rurales, amén de las distancias entre una estancia y otra, pero más aun considerando que para la época un número tal de sujetos congregados al son de la música y el alcohol difícilmente podía pasar desapercibido para los corregidores, los alcaldes de la Santa Hermandad, y para los mismos habitantes rurales.

Sin embargo, dicha interrogante no es central al analizar la representación española de las borracheras. Lo importante era que dicho relato se consideraba válido, con lo cual la sospecha respecto de los indígenas, sumado a su carencia de educación evangélica, se volvía a hacer presente. En la medida que menos integrados estaban éstos a la vida "en policía cristiana", mayores eran las posibilidades que se alzaran junto a los rebeldes de la Araucanía y esto aumentaba con la llegada, probablemente en pequeñas pero constantes cantidades, de esclavos indígenas y migrantes voluntarios desde las llamadas tierras de guerra a Chile central.

Cuesta poco imaginar que, a cien años de la entrada española en territorio chileno, si los indígenas de la zona más antigua de colonización precariamente conocían las oraciones, quienes venían de los lindes del río Biobío o de más al sur, menos evangelizados estaban. Precisamente era la adopción del cristianismo el elemento que posibilitaba la integración cultural y social al mundo colonial, pues el esfuerzo evangelizador iba mucho más allá (o al menos lo debiera hacer) de que los indígenas aprendieran la mecánica de la persignación o el texto de las oraciones, para hacerlos adecuarse a una serie de creencias, modos de hacer, costumbres y hábitos en los que sus comportamientos, públicos y privados, eran reflejo de una forma de vida. Por ello es que las referencias a las borracheras no se acababan en el consumo desmedido de alcohol, y sus consecuencias en el ausentismo laboral, sino que apuntaban a establecer el conjunto de prácticas que se derivaban de ello, entre las que se contaban las pendencias, el libertinaje sexual y la adoración al demonio o a otros espíritus no cristianos. Cada una de ellas era un paso hacia atrás en el proceso de integración a la sociedad colonial y su permanencia o, incluso, su retorno a la "barbarie". En tal reflexión, de ahí a la rebelión solo había un paso.

Por lo anterior es que durante el alzamiento de 1655, cuyas primeras y violentas acciones ocurrieron durante febrero de dicho año, e incluyeron la quema y el saqueo de capillas e iglesias fronterizas así como la profanación de sus imágenes, no resulta sorprendente que el gobernador Antonio de Acuña y Cabrera dictará un bando que prohibía las borracheras, los juegos de chueca, que los indígenas anduvieran a caba1lo, y aun que se movilizaran fuera de sus lugares de asentamiento, en particular de

60 Declaración del licenciado Luis de Toledo, clérigo presbítero. Santiago de Chile, 15-II-1642. AGI, Escribanía de Cámara de Justicia, 929C, ff. 23r-23v. 
las estancias, sin autorización escrita de su encomendero o de sus mayordomos. Esto nacía del temor que, como medio siglo antes, la guerra se extendiera a la jurisdicción capitalina $^{61}$. La dictación de ese bando era esperable dada la acumulación de desconfianza y miedo, así como a la situación que en esta nueva guerra no eran solo los cacicazgos de tierra adentro los que se habían alzado. También lo habían hecho todos aquellos indígenas denominados yanaconas; los domésticos, es decir, los migrantes voluntarios llegados desde la Araucanía; y los encomendados originarios de Maule e Itata. A ellos habría que sumar a los esclavos tomados antes de estallar este conflicto, y que se encontraban distribuidos por todo el reino. Por lo anterior, el peligro de que el alzamiento rebasara las orillas del río Maule, lo que ya era una situación militarmente compleja y crítica, hacía que se tomaran estas medidas.

Sin embargo, dicho bando resultó ser una reacción tardía a la vez que anacrónica, pues como el propio Acuña y Cabrera pudo comprobar, el alzamiento o al menos algunos intentos rebeldes ya había alcanzado los partidos situados al norte de Santiago. Peor aún, según los antecedentes aportados por el corregidor de La Serena, la conspiración se había extendido, y hacía más de un año que los portadores de la flecha recorrían los valles serenenses llamando a la guerra. Ello había derivado en el descubrimiento de tal concertación rebelde, el apresamiento de sus principales cabecillas, y su posterior ajusticiamiento. Haciendo una relación de los autos incoados contra los alzados, el corregidor informó a Acuña y Cabrera que:

antes de este alçamiento pasaron unos yndios al balle de Copiapo y llebaron la flecha que se lo dixo el cazique don Salbador [...] assimismo confiessa en su confession un yndio llamado Juan Clelmo como antes de este alçamiento bino un yndio a traer la flecha y passo en cassa de Juan Quilancari = y assimismo declaro en esta caussa el cazique don Bartolo [...] como antes que binieron dichos mensajeros a conbocar esta jurisdiçion abian benido otros dos yndios mensajeros a traer las flechas en otras ocasiones $[\ldots]^{62}$.

Tales palabras reflejaban la aparente impunidad con que los werkenes se habían movido por la geografía del Norte chico, pero también la disgregación de los pobladores indígenas en la zona, cuestión que ya no afectaba solo a los evangelizadores, sino también a los que pretendían llevar la guerra hasta lugares que por más de un siglo no había visto estallar conflictos de esta índole. Aun así, al parecer, algunos lugares se sumaron a la rebelión. Otras informaciones apuntaban a que en los valles de Quillota y de La Ligua, así como en ciertos parajes cercanos a la ciudad de La Serena, había indígenas decididos a alzarse, quienes solo esperaban el momento propicio para hacerlo. Éste no llegó, y la represión se tendió sobre ellos, aunque tanto los corregidores como sus tenientes difícilmente pudieron dar fe de haber detenido a todos los sospechosos, por lo cual la sospecha continuó en los años venideros con

${ }^{61}$ Bando del gobernador don Antonio de Acuña y Cabrera que prohíbe las borracheras y juegos de chueca de los indios. Santiago de Chile, 11-VII-1655. AGI, Escribanía de Cámara de Justicia, 932b, pza. 14a , ff. 881r-882v; Acta del cabildo de Santiago de 16 de julio de 1667. Santiago de Chile, 16-VII-1667, CHCh. t. XXVII, 1909: $182-185$.

${ }^{62}$ Certificación del general Juan Ruiz de Peralta sobre las causas criminales contra los alzados de su corregimiento. La Serena, 16-VIII-1655. AGI. Escribanía de Cámara de Justicia, 932b, pza. 1ª f 89r. 
una carga de desconfianza contra los indígenas, sus espacios de socialización, y su cristianismo.

Mientras tanto, el alzamiento se generalizaba en la Araucanía con su carga de derrotas, temor y desconfianza, a su vez los hombres de Chile central eran movilizados sin importar el color de piel ni el origen étnico de quienes concurrían a la guerra, pues tanto fueron alistadas compañías milicianas de mulatos libres, como los tributarios de las encomiendas tuvieron que tomar los bártulos de sus amos para marchar en su servicio. En tanto, la vigilancia sobre las borracheras se hacía cada vez más intensa y, probablemente, entre funcionarios y eclesiásticos al menos rondaba la pregunta de cuántas veces los indígenas habían estado al borde del alzamiento, y no lo habían concretado.

\section{Conclusiones}

En el último cuarto del siglo XVI, según la percepción de las autoridades del Cabildo de Santiago, hubo un resurgimiento de las borracheras indígenas. Estas, en principio, solo fueron concebidas como espacios de juerga y descontrol etílico y sexual, sin mayor significación ritual o política, pero recurrentes y masivas. No había patrones claros para su realización: bien podían celebrarse en ocasión de una boda, o de una festividad religiosa cristiana, lo que dificultaba grandemente su represión y el castigo de sus participantes. No obstante, a medida que pasaba el tiempo dichos eventos comenzaron a ser percibidos como algo más que una simple juerga. En ellos no solo se bebía hasta el hartazgo, o se daba rienda suelta a los apetitos sexuales. También se idolatraba y apostataba, lo que aumentó tanto la preocupación de las autoridades, como las medidas para reprimirlas. Lo anterior en un contexto en el que la evangelización de estos mismos indígenas era un proceso precario, encargado a algunos eclesiásticos, a los pocos frailes que había en Chile y hasta a algunos laicos, y cuyos resultados levantaban serias dudas.

Paralelamente a Chile central y el Norte chico comenzaron a llegar un importante número de migrantes indígenas. Algunos, en especial los que arribaban de otros reinos, venían de forma voluntaria. Otros, particularmente los originarios de Araucanía, Valdivia y Chiloé, lo hacían forzados. Si bien la esclavitud indígena era ilegal, la captura de "piezas" en la guerra, o el traslado de los tributarios mapuches a las propiedades de sus feudatarios en los valles centrales era usual, y sin gran dificultad se encontraban subterfugios para legitimarlo. Pero con ellos también viajaban su idioma, sus costumbres y su religión; y si en los territorios donde llegaban el conocimiento evangélico entre los indígenas era precario, en su caso, probablemente, éste ni siquiera existía.

Chacras y estancias, así como la propia ciudad de Santiago, eran lugares donde los migrantes forzosos fueron puestos a trabajar. Allí convivían y se emparentaban con los originarios de la región central; allí también, a modo de hipótesis, reforzaron el uso del mapudüngún, reintrodujeron el palín y comenzaron a celebrar borracheras juntos. Estas, en la percepción hispana de fines del siglo XVI, se hicieron más complejas, al mismo tiempo que se empezó a pensar en ellas como en instancias donde era posible conspirar y rebelarse. Lo anterior se hizo realidad a propósito del alzamiento general de 1598, cuando el corregidor de Santiago reprimió una concertación rebelde al norte de Santiago, resultando varios indígenas ajusticiados. Con ello se hacía carne uno de los más grande temores de los españoles, que era que la comuni- 
cación entre los migrantes forzosos y sus parientes rebeldes no se hubiera cortado, lo que permitiría que los werkenes de los alzados se desplegaran por Chile llamando a la guerra, seguros de tener quien acogiera sus mensajes.

Ello no solo aumentó la desconfianza española respecto de los indígenas, sino que los llevó a aumentar su vigilancia, a controlar sus costumbres, a reforzar la evangelización y a reprimir con mayor fuerza las borracheras y los juegos de chueca. Sobre todo, y en la medida que las concertaciones rebeldes eran necesariamente clandestinas, había de estar atento a lo que se hablaba en las calles, aunque muchas veces esos rumores no eran sino embustes o noticias distorsionadas. Así lo demostró la movilización militar de 1630 . Pero también lo hizo respecto de hasta dónde se extendían el miedo a un otro desconocido y peligroso, que bien podía estar mezclado entre los pacíficos peones indígenas, pues exteriormente no se diferenciaba de ellos.

Era la adopción del cristianismo el elemento que posibilitaba la integración cultural y social de los indígenas al mundo colonial. Su evangelización implicaba no solo el conocimiento de los ritos y las ceremonias cristianas, sino también el adecuarse a una serie de creencias, modos de hacer, costumbres y hábitos en los que sus comportamientos, públicos y privados, eran reflejo de una forma de vida. Por ello es que preocupaba la recurrencia de las borracheras, cuya representación no acababa con describir el consumo desmedido de alcohol y sus consecuencias en el ausentismo laboral, sino que apuntaba a establecer el conjunto de prácticas idolátricas que se derivaban de ello. Cada una de estas era un paso hacia atrás en el proceso de integración a la sociedad colonial y su permanencia o, incluso, su retorno a la "barbarie". De allí a la rebelión solo había un paso.

De modo tal, en 1655 cuando las lanzas mapuches volvieron a golpear con fuerza en la frontera, los esclavos y migrantes forzosos que se encontraban en Chile central y el Norte chico, participantes de borracheras y jugadores de palín, seguían siendo concebidos como un enemigo en potencia, capaz de "contaminar" a los habitantes indígenas de Chile central. Ayudados por el aislamiento de los grandes parajes rurales, surcados de ríos y malos caminos, solo esperaban el momento preciso para liberarse del yugo de la esclavitud o del servicio personal. Todo ello, sin embargo, transitaba por una línea sutil, en gran medida imposible de determinar, e incluida en un gran espacio de interpretación que alimentado por hechos y procesos, como las borracheras y la guerra, hacía que el miedo y la desconfianza al otro se convirtiera para los españoles en la forma más recurrente de pensar al conjunto de los indígenas.

\section{Referencias bibliográficas}

Bacigalupo, Ana Mariella. "El rol sacerdotal de la machi en los valles centrales de la Araucanía”. En ¿Modernización o sabiduría en tierra Mapuche?, editado por Marileo, Armando. Santiago: Ediciones Paulinas, 1995, 51-95.

Barros Arana, Diego. Historia General de Chile [1884], tomo III. Santiago: Editorial Universitaria, 2000.

Boccara, Guillaume. Los vencedores. Historia del pueblo mapuche en la época colonial. Antofagasta: Universidad Católica del Norte, 2007.

Contreras, Hugo. "Aucas en la ciudad de Santiago. La rebelión mapuche de 1723 y el miedo al otro en Chile central". Anuario de Estudios Americanos, $n^{\circ}$ 70-1 (2013), 67-98. DOI: https://doi.org/10.3989/aeamer.2013.1.03 
- "Borracheras, huidas y rebeldía entre los indios de Chile colonial. Decretos, autos y bandos de los siglos XVI y XVII". Corpus. Archivos virtuales de la alteridad americana, $\mathrm{n}^{\circ}$ 4-1 (2014). Disponible en https://corpusarchivos.revues.org/642

- "Robos, juegos y borracheras de indios. Sociedad indígena y representaciones españolas tempranas en Chile central, 1540-1560". Memoria Americana, no 24-2 (2016), 39-57.

- "Indios de tierra adentro en Chile central: Las modalidades de la migración forzosa y el desarraigo (fines del siglo XVI y comienzos del XVII)". En América en Diásporas. Esclavitudes y migraciones forzadas en Chile y otras regiones americanas (siglos XVI-XIX), editado por Valenzuela, Jaime. Santiago: Ril Editores, 2017, 161-196.

Errázuriz, Crescente. Seis años de la Historia de Chile (23 de diciembre de 1598-9 de abril de 1605). Santiago: Imprenta Cervantes, 1908.

Espino, Antonio. La conquista de América. Una revisión crítica. Barcelona: RBA libros, 2013.

Fernández, Enrique, S.J. (ed.). Monumenta Peruana VIII (1603-1604). Roma: Institutum Historicum Societatis Iesu, 1986.

Foërster, Rolf. Introducción a la religiosidad mapuche. Santiago: Editorial Universitaria, 1993.

Goicovich, Francis. “Alianzas geo-étnicas en la segunda rebelión general: génesis y dinámica de los vutanmapus en el alzamiento de 1598". Historia, no 39-1 (2006), 93-154.

Jara, Álvaro. "Importación de trabajadores indígenas en el siglo XVII". Revista de Historia y Geografia, $\mathrm{n}^{\mathrm{o}} 124$ (1958), 177-212.

López, Carlos. "La prohibición del palín o chueca en Chile entre los siglos XVII y XVIII". Aloma, no 25 (2009), 91-117.

Mariño de Lobera, Pedro. Crónica del reino de Chile. Santiago: Imprenta del Ferrocarril, 1865.

Michielli, Carolina Teresa. Realidad socioeconómica de los indígenas de San Juan en el siglo XVII. San Juan: Universidad Nacional de San Juan, 1996.

- "Paltata Entyu: ofrendas para cruzar la cordillera". En Culturas surandinas. Huarpes y Diaguitas, editado por Volantines, Arturo. Coquimbo: SCAL, 2011, 295-309.

Muñoz, Juan Guillermo. "La esclavitud indígena. El caso de Colchagua". Revista de Historia Social y de las Mentalidades, $\mathrm{n}^{\circ}$ 7-2 (2003), 113-147.

- "Viñas en la traza de Santiago del Nuevo Extremo y chacras colindantes (siglos XVIXVII)". Revista de Historia Social y de las Mentalidades, n 10-1 (2006), 121-177.

- "María de Niza, sus dos maridos, familia, viña y alambique. Santiago, siglo XVI". Rivar, $\mathrm{n}^{\mathrm{o}} 3$ (2014), 104-115.

Oviedo, Carlos (ed.). "Sínodo diocesano de Santiago de Chile celebrado en 1626, por el ilustrísimo señor Francisco González de Salcedo". Historia, no 3 (1964), 313-360.

Palma, Daniel. La rebelión mapuche de 1598. Santiago: Tesis de Licenciatura en Historia, Universidad Católica de Chile, 1995.

Ramón, Armando de (ed.) "La encomienda de Juan de Cuevas a la luz de nuevos documentos (1574-1583)". Boletín de la Academia Chilena de la Historia, nº 62 (1960), 52-107.

Rosales, Diego de. Historia General del Reino de Chile. Flandes Indiano [1674], III tomos. Valparaíso: Imprenta del Mercurio, 1877-1878.

Ruiz, Carlos. "Insurrecciones indígenas en Chile central, 1598-1825”. Alamedas, nº 6 (1999), 80-94.

- "Mucho y muy buen vino. Producción vitivinícola en la zona norte de Santiago (siglos XVI -XVIII)". Revista de Historia Social y de las Mentalidades, nº 10-1 (2006), 55-92. 
Valenzuela, Jaime. "Indígenas andinos en Chile colonial: Inmigración, inserción espacial, integración económica y movilidad social (Santiago, siglos XVI-XVII)". Revista de Indias, vol. LXX-250 (2010), 749-778. DOI: https://doi.org/10.3989/revindias.2010.024

- "La cruz en la cristianización jesuita de Chile meridional: signo, significados y paradojas (1608-1655)". En La mediación lingüístico-cultural en tiempos de guerra: cruce de miradas desde España y América, editado por Payàs, Gertrudis - Zavala, José Manuel. Temuco: Ediciones Universidad Católica de Temuco, 2012, 189-216.

- "Indios urbanos: inmigraciones, alteridad y ladinización en Santiago de Chile (siglos XVI-XVII)". Historia Crítica, no 53 (2014a), 13-34. DOI: https://dx.doi.org/10.7440/ histcrit53.2014.01

- "Indios de arriba en Santiago de Chile según los registros de bautismo: entre el auge esclavista, la reconstrucción urbana y el abolicionismo (1665-1685)". Chungara, no 46-4 (2014b), 625-636.

Zúñiga, Jean-Paul. "Les esclaves africains et leurs descendants à Santiago du Chili (XVII siècle)". En Un juego de engaños. Movilidad, nombres y apellidos en los siglos XV a XVIII, editado por Salinero, Gregorio - Testón, Isabel. Madrid: Casa de Velázquez, 2010, 187-207. 